DOI 10.37882/2223-2982.2020.07-2.21

\title{
СПОСОБЫ ПЕРЕДАЧИ ЧУЖОЙ РЕЧИ В РУТУЛЬСКОМ ЯЗЫКЕ
}

\section{METHODS OF TRANSMITTING SOMEONE ELSE'S SPEECH IN THE RUTUL LANGUAGE}

\section{S. Makhmudova}

Summary: In linguistics, two forms of transmitting someone else's speech are traditionally distinguished - direct speech and indirect speech. The forms and methods of transmitting someone else's speech in the Rutul language, which relates to the Lezgi languages of the Nakh-Dagestan subgroup of the Iberian-Caucasian languages, did not serve as a subject of special consideration in the scientific literature. This work is the first attempt to describe the methods of transmitting someone else's speech in the Rutul language.

Keywords: Iberian-Caucasian languages, Daghestan languages, Rutulian language. Methods of transmitting speech, direct speech, improperty direct speech. The communicative strategy of the speaker.
Махмудова Светлана Мусаевна

Д.филол.н., профессор, Московский Государственный Психолого-педагогический Университет, Москва rutulsveta@mail.ru

Аннотация: В лингвистике традиционно выделяются две формы передачи чужой речи - прямая речь и косвенная речь. Формы и способы передачи чужой речи в рутульском языке, относящемся к лезгинским языкам нахско-дагестанской подгруппы иберийско-кавказских языков, не служили в научной литературе предметом особого рассмотрения. Данная работа является первой попыткой описания способов передачи чужой речи в рутульском языке.

Ключевые слова: иберийско-кавказские языки, дагестанские языки, рутульский язык. Способы передачи чужой речи, прямая речь, косвенная речь, несобственно-прямая речь. Коммуникативная стратегия говорящего. рямая речь - это речь героя, переданная без изменений. Косвенная речь интерпретирует чужое высказывание и представляет собой коммуникативно ориентированное описание способов передачи чужой речи. Прямая и косвенная речь в рутульском языке особо не выделяются паузами до или после авторской речи. Несобственно-прямая речь понимается как лингвостилистическое и прагматическое явление в синтаксисе текста, при которой автор текста передает чужую внутреннюю речь, не проецирующуюся на слушателя непосредственно [8].

В рутульском языке чужая речь свободно произносится в любой позиции по отношению к авторским словам как обычный развернутый член предложения. Для передачи чужой речи имеются глаголы и специальные маркеры, восходящие к данным глаголам - гьухьури "сказал", хьури "сказал", рухьура "говорит", гьухьуси "скажет", хьуси "скажет", хьире "говоря", хьва "говорит, сказал", хьур "сказав". Маркеры, передающие семантику чужой речи, в рутульском языке могут иметь не только данное значение, но и более глубинную семантику. В фольклоре, в сказках, плачах (хул "плач" - распространенный жанр рутульского фольклора) маркеры чужой речи выполняют свою собственную роль, передавая динамизм и экспрессию действия, в связи с чем в данной статье способы передачи прямой и косвенной речи будут рассмотрены на примере рутульской сказки.

Для передачи и прямой, и косвенной речи в рутульском языке обычно используется маркер хьва "сказал, говорит, сказали, говорят", который может выступать неоднократно даже в составе одного и того же предложе- ния. Маркер хьва обозначает прошедшее время, событие, которое имело несколько раньше или уже давно. Хива имеет семантику передачи речи третьего лица, о котором говорят говорящий и слушающий, часто маркер хьва используется в сказках. Данный маркер свободно передвигается по предложению, выступая неоднократно в составе одного и того же предложения и после любого члена без ограничений (пример (1).

(1) Авал, авал а-й-адиш-ий, хьва, са эдеми.

давно давно был-прош.-не был-прош. говорят один человек-абс.п.

Сада, хьва, ми эдеми, хьва, руъу-ра

один раз говорят этот-абс.п. человек-абс.п. говорят идти-наст.

дам- $a$, ы-в-ырга-ра , хьва, минийде джиляа

лес-ин-эсс. найти-3-наст. говорят этот-ад-эсс. полин-эсС.

са кьути. Къизил-гымыш ад

один коробка-абс.п. золото-серебро-абс.п. иметьсядеепр.

калагу-р, хьва, си-в-ти-р духул,

показаться-деепр. говорят ударить-3-деепр. каменьабс.п.

палта, гьайвыр ачых в-аъа-ра, хьва ми-ний-е

топор-абс.п. быстро открыть 3-делать-наст. говорят этот-эрг.п. 
ми кьути. Кьути ачых в-ыбы-йне, хьва,

этот коробка-абс.п. коробка-абс.п. открыть 3-делатьконверб говорят

араа гъаъ игъ-в-илхьва-ра са эккед, мыкьлад са изнутри наружу выбираться-3-наст. один большой страшный один

шей.

чудовище -абс.п.

Давным-давно, жил, говорят, один человек. Один раз, говорят, пошел этот человек в лес, нашел этот человек на земле одну коробку. Подумав, что там золото-серебро, разбив коробку камнем и топором, быстро открывает этот человек эту коробку. Когда он открыл коробку, говорят, оттуда вышло большое страшное чудовище.

Недавно прошедшее время в диалоге обозначается маркером прямой и косвенной речи хьури, употребляющимся как до чужих слов, так и после них, он также может употребляться в одном и том же предложении один раз или несколько раз в зависимости от длины предложения. Например:

(2) Джи видж субда ваъара, шей-ере

само-эрг.п. сам-абс.п. трясти делать-деепр. чудовищеэрг.п.

хьу-ри - 3-а вы уле-си! - хьу-ри.

сказать-прош. я-эрг.п. ты-абс.п. съесть-буд. сказатьпрош.

Тряся себя, чудовище сказало: -я тебя съем!

Маркер хьире употребляется для передачи чужой повторяющейся речи:

(3) Гич1 йы-в-хы11-р, - Гу-в-к- $а$, гу-в-к-, , хьире,

испуг-абс.п. удариться-3-деепр. подождать-3-имп. сказать

хъаха-с чалыш руъу-ра ми эдеми.

убежать-инф. стараться стать-наст. этот-абс.п. человек-абс.п.

- Подожди! Подожди! - говорит человек и пытается убежать.

Маркер рухьура передает динамику прямой и косвенной речи:

(4)- 3-а вы кьути-яа гъаъ эхъеп1и-ри, -

я-эрг.п. ты-абс.п. коробка-ин-абл. наружу вытащитьпрош.

рухьу-ра миний-е, - в-а за-с гьеми хатир

говорить-наст. этот-эрг.п. ты-эрг.п. я-дат.п. такой добро-абс.п. и-ме хъаъа-д?

являться-вопр.н. сделать-прич.

Я тебя освободил из коробки, таким добром ты хочешь мне отплатить?

Pухьура так же может следовать перед или после чужой речи:

(5) Шейере рухьура: Ва1, илсанар, хатир гьац1абыр диъиме?

Чудовище говорит: Разве вы, люди, знаете, что такое добро?

(6) -Вите, худкас тини гид хукадаа, гьалыс ва1 хатирес хатир хъыъырди, - рухьура шейере.

Пойдем, спросим у того дерева, кому вы отплатили добром за добро, - говорит чудовище.

Маркер хьур используется также для понуждения второго лица произнести те слова, которые инициирует спикер, например:

(7) Дыхьыр мибыр, хукас йишид кал ихтилат гьаъара, хьели эдемиере рухьура: - Джан хук, гьихьяъ ми шейеде видж нагьакь виъи, хьур!

Идут они к дереву, рассказывают ему все как было, и спрашивает человек: Милое дерево, скажи этому чудовищу, что оно неправо!

Маркеры хьур, хьире, гьухьури, рухьура, хьури могут оформлять и косвенную речь, при этом прямая речь становится придаточной частью сложного предложения, например:

(8) Вакьалкьара, гьухьури хукара, джи эдемиес емишбыр выри, хьур, сиг1ыд йыгъа а1хъ выбыри, хьур, эдемиере, хьуйне, га1рибыр кьат гьаъара, дибехьде ругбыр салтара, хьур, ц1ай ки кихъийир, хъу1гъу1ре, рухьура хукара, - Вы люъур йчгад и!.

Задрожало дерево и сказало, что оно давало человеку свои плоды, в жаркий день укрывало его тенью, а человек ломал его ветви, оставлял мусор около корней, а потом еще и поджигал, когда уходил, - говорит дерево, - Тебя надо съесть!

Для усиления семантики динамизма и драматичности происходящего действия в рутульском языке используется сразу два маркера чужой речи, например:

(9) - Ун йишириме?! Гьамыъ за вы улеси! - рухьура, хьва, шейере.

Слышал, теперь я тебя съем! - говорит чудовище.

Для выражения семантики высшей степени напряженности действия прямая речь в диалоге передается 
без всяких маркеров или слов автора:

(10)- Джан шей, тини гид йыма1ледаа ки хухъудкаси!

- Дорогое чудовище, давай еще и у того осла спросим!

Интерес представляют конструкции передачи чужой речи, где одна речь - речь автора, заключает в себе вставленную конструкцию - прямую речь, в которую вставлена косвенная речь, например:

(11) Эдемиере рухьура , гьай джан йыма1л, зас куьмег гьаъ, ми шей заа шыв хьур сывхы1р ад виъи!

Человек говорит, о осел, помоги мне, что хочет от меня это чудовище?!

Еще один способ оформления прямой речи - при помощи маркера -ки, сопровождающего маркер косвенной речи:

(12) Йыма1лере, хъавацур мибишихда, рухьура ки: шей гьакь виъи, за вас гьадухъун гвалах выбыри, ва зы кьа1сва1 ле гъаъ йивигыри. Гьакьна улере вы гьадире!

Осел послушал их и говорит: - Чудовище право, я столько работал на тебя, а ты выгнал меня, когда я постарел. Правильно оно тебя кушает!

Как демонстрирует материал рутульского языка, маркер -ки в дискурсе обозначает ответную реплику на уже ранее в диалоге прозвучавшую реплику. То есть рутульский язык располагает специальным маркером для ответной реплики.

Маркер - ки сохраняется и при изменении прямой речи в косвенную, при этом личное местоимение зы меняется на рефлексивное джи (эрг.п.), видж (абсолютивный падеж). В тексте, состоящем из нескольких грамматических основ, после каждой употребляется маркер xьyp.

\section{Например:}

(13) Йыма1лере, хъавачур мибишихда, рухьура ки: шей гьакь виъи, хьур, джи вас гьадухъун гвалах выъыри, хьур, ва видж кьа1сва1ле гъаъ йивигыри, хьур. Гьакьна улере вы гьaдире, хьур.

Осел, послушав их, говорит, что чудовище право, что он столько работал на тебя, а ты его выгнал на старости лет. Говорит, что правильно тебя кушают.

Прямая речь может быть заключена в авторские слова как вставленное предложение (14), авторские слова могут следовать перед прямой речью (15), авторские слова могут следовать за прямой речью (16), сама же прямая речь может передаваться без изменений, например:
(14) Маа эдеми-ере шей-е-де - В-ыкь-а за на ва са гьалдаа-га ки хухъудка-си! - рухьура.

Опять человек чудовищу - Давай еще у кого-нибудь спросим! - говорит.

(15) Шей-е-ре рухьура - Ваъ, за вы улеси!

Чудовище отвечает: - Нет, я тебя съем!

(16) Выкьа гьетини гид тылы-е-даа ки хухъудка-си! рухьура эдеми-е-ре.

Давай спросим еще и у той собаки! - говорит человек.

В сказках или длинных текстах со своей фабулой повтор одного и того же маркера в нескольких предложениях диалога подряд и несколько раз в последнем предложении имеет одно очень важное значение: безысходность, нерешаемость проблемы, безвыходность долго тянущегося тяжелого положения, маркер чужой речи выполняет роль рефрена, например:

(17) Йиъид-йиъид кал ихтилат гьыъыр, эдемиере рухьура - Гьай джан тыла, - рухьура, - выш гьакь йиъи е-клаа? - рухьура.

Рассказав все по порядку, человек говорит: - Милая собака, - говорит,- кто из нас прав?

При изменении прямой речи, содержащей вопрос, в косвенную, в предикате вопросительной части появляется формант -ди, тем самым преобразующий вопросительное предложение в относительное:

(17а) Эдемиере хулкара, джва1ршикляа выш гьакь йиъиди.

Человек спрашивает, кто из них прав.

Экспрессию торжественности, семантику глубокой эмоциональности, разрешения ситуации в рутульском языке передает маркер чужой речи, только в подобном исключительном случае выступающий в начале предложения. В данном случае маркер чужой речи приобретает семантику ремы предложения:

(18) - Рухьура тылые-ре: - Шууна мисед кьухьды шей к1ыъды кьутие ай? - рухьура тылыере, - Зы ки гьу1мирлых илсанас гвалах выбыр, хал уху1р, халаа йивигыд виъи, - рухьура тылыере, - йидж зы ва1гьа1 инамиш диш! - рухьура тылыере.

Отвечает собака: - Как такое большое чудовище залезло в такую маленькую коробку? - говорит собака, - Я тоже всю жизнь на человека работала, дом стерегла, но меня человек тоже человек выгнал, но я не могу поверить вам! - говорит собака.

Как демонстрирует предложение, в данной части рутульской сказки слова автора повторяются неоднократ- 
но, и в каждом случае маркер чужой речи - глагол выступает в несвойственной маргинально левой позиции, тем самым передавая значение боли и стыда человека за свое поведение.

(19) Хьум йишир, кьутие ухъу1вгъу1ре шей: -Гьын, хьури тылыере, - гъигъе хъаваъ кьути.

Превратившись в дым, забирается чудовище обратно в коробку: - Ну, говорит собака, - закрой обратно коробky.

В последнем предложении рассказчиком только один раз используется наиболее частый, нейтральный маркер хьури, передающий прошедшее время, предложение же при этом приобретает семантику катарсиса, совершившегося в теперь уже обновленной душе человека. Данный маркер, обозначающий прошедшее время, имеет еще один, более глубокий смысл, - эгоистичное поведение человека по отношению к животным и к природе осталось в прошлом.

Повелительное предложение рутульского языка не различает прямую и косвенную речь, сравните пример (19) с прямой речью и пример (20) с косвенной речью:

(20) Тылыере хьури: - Гьын, гъигъе хъаваъ кьути, - хьуpu.

Собака сказала, ну теперь закрой обратно коробку, сказала.

Несобственно-прямая речь - это особое лингвостилистическое средство, при которой в центре внимания оказывается внутренняя речь, которая имеет собственную коммуникативно-прагматическую характеристику.
Несобственно-прямая речь является выведенным из потока сознания течением мысли, обращенной к себе самому, размышлением героя в рамках авторского изложения. Несобственно-прямая речь служит своеобразной вводной частью сюжета повествования, объясняющим дальнейшие поступки героя. Для передачи несобственно-прямой речи в рутульском языке используется форма сослагательного наклонения с формантом -ий, ий+меди [6]:

\section{Яраб, гьис джиркьыдий ми гада?}

Интересно, почему не пришел этот мальчик?

Мибише мыс высдий зас хьыв?

Когда же они накормят меня?

Гъиигъа нин рыкьасиймеди?

Сегодня придет ли мама?

Таким образом, вышеприведенный материал позволяет сделать несколько выводов:

- для передачи как прямой, так и косвенной речи в рутульском языке используются одни и те же маркеры;

- преобразование прямой речи в косвенную обозначается только изменением личных местоимений и имен на притяжательные и рефлексивные местоимения;

- прямая речь, преобразованная в косвенную, образует сложное предложение, где слова автора являются главной клаузой, косвенная речь - придаточной клаузой;

- маркеры прямой и косвенной речи выполняют в рутульском языке не только техническую, но и экспрессивную функцию.

\section{ЛИТЕРАТУРА}

1. Арутюнова Н.Д. Предложение и его смысл. Логико-семантические проблемы. М.: Наука, 1976.

2. Байдикова Н.Л. Формально-стилистические характеристики способов передачи чужой речи (на материале англоязычных художественных произведений)//Научный диалог. 2018. № 3. Стр. 19-32.

3. Гаджиев М.М. Синтаксис лезгинского языка. Ч.2. Сложное предложение. Махачкала, 1963.

4. Кодухов В.И. Прямая и косвенная речь в современном русском языке. -М.-Л., 1957.

5. Махмудова С.М. Способы выражения субъектно-объектных отношений в рутульском языке. Автореф. дисс. на соиск. уч. ст. к.филол.наук /С.М. Махмудова. - Махачкала, 1995.

6. Махмудова С.М. Грамматические классы слов и грамматические категории рутульского языка. Автореф. дисс. на соиск. уч. ст. д. филол. наук /С.М. Махмудова. - М., 2002.

7. Милых М. К. Конструкции с косвенной речью в современном русском языке. - Издательство Ростовского университета, 1975.

8. Омелькина 0.В. Несобственно-прямая речь как лингвопрагматическая категория. Автореф. дисс. на соиск. уч.ст. к. филоло.н. Самара, 2007.

9. Тестелец Я.Г. Введение в общий синтаксис. М., 2002. 